\title{
Perspectives of Using Interactive Slides in ESL Classroom among Primary School English Language Teachers in Pasir Gudang
}

\author{
Tan Hon Kian, Tharani A/P Paramasivam, Kokilavathi A/P Paramesvaranm, Selvakumari A/P \\ Sandrasakeren
}

\begin{abstract}
In technological society, technology plays a crucial role as an integral part of teaching. This research aimed to know teachers' perspective of using interactive slides in ESL classroom. The population of this research comprises national primary school teachers from Pasir Gudang district. A total of 179 respondents participated in this research. This calculation on the number of respondents was based on Krejcie and Morgan's (1970) table. The data were gathered via questionnaires and semi-structure interviews. The gathered data were analysed using descriptive analysis method in terms of frequency, percentage, mean and standard deviation. The researchers conducted saturated semi-structured interviews to support the findings through questionnaires. The findings of the research revealed that Interactive Slide (IS) is effective to use in the ESL classroom. The study also showed the challenges faced by teachers in using IS. The implication of this research suggested that schools should provide adequate facilities in encouraging teachers to use IS in ESL classrooms and organise activities or programs for teachers to enhance their IS skills. In future researches, it is recommended to widen the population of respondents to other districts or states.
\end{abstract}

Keywords: ESL classroom, interactive slides, teachers, perspective, interactive slides

\section{INTRODUCTION}

In technological society of the 21 st century, information, multimedia and technology skills are vital tools for educators in disseminating knowledge to pupils. Katwibun (2014) stated these tools are needed due to the environment of technology and media. The use of technology in ESL classroom have grown rapidly as educators today explore and use technology to facilitate teaching and learning (TnL) process. Malaysia has long recognised the transformative potential of information and communication technology (ICT) in education. The UNESCO noted that Malaysia was among the first few countries in the world to have pioneered a strategic ICT plan for its education system (Ministry of Education, 2015). The goal is to exploit the potential of ICT to enhance the depth and improve the overall quality of education. ICT is also one of the shifts to transform the system in Malaysian Education Blueprint 2013-2025 (Ministry of Education,

Revised Version Manuscript Received on April 19, 2019.

Tan Hon Kian, Faculty of Social Sciences and Humanities, Universiti Teknologi Malaysia, Skudai, Johor, Malaysia.

Tharani A/P Paramasivam, Faculty of Social Sciences and Humanities, Universiti Teknologi Malaysia, Skudai, Johor, Malaysia.

Kokilavathi A/P Paramesvaranm, Faculty of Social Sciences and Humanities, Universiti Teknologi Malaysia, Skudai, Johor, Malaysia.

Selvakumari A/P Sandrasakeren, Faculty of Social Sciences and Humanities, Universiti Teknologi Malaysia, Skudai, Johor, Malaysia.
2015). Various technological tools have been introduced in educational settings namely interactive technology, interactive whiteboard and interactive slides (IS). However, the use of interactive slides is limited in ESL classroom. Although there are many studies (Bidaki \& Mobasheri, 2013; Cuthell, 2005; Kennewell \& Beauchamp, 2007; Kennewell, Tanner, \& Parkinson, 2000; Razavi, Ghanizadeh, \& Akbari, 2016; Rostami, Akbari, \& Ghanizadeh, 2015) on interactive technology and interactive whiteboard stating that they are widely used in ESL classroom, less studies conducted interactive slides. Hence, the purpose of this paper is to know teacher's perspective on the effectiveness of Interactive Slides in the classroom.

\section{A. Research Objectives}

I. To investigate the teachers' perspective on the effectiveness of using Interactive Slides (IS) in ESL classroom among primary school English Language teachers in Pasir Gudang.

II. To identify the teachers' perspective on the challenges of using IS in ESL classroom among primary school English Language teachers in Pasir Gudang.

III. To find out the teachers' perspective on the ways to encourage teachers to use IS in ESL classroom among primary school English Language teachers in Pasir Gudang.

\section{B.Research Questions}

I. What is the teachers' perspective on the effectiveness of using Interactive Slides (IS) in ESL classroom among primary school English Language teachers in Pasir Gudang?

II. What is the teachers' perspective on the challenges of using IS in ESL classroom among primary school English Language teachers in Pasir Gudang?

III. What is the teachers' perspective on the ways to encourage teachers to use IS in ESL classroom among primary school English Language teachers in Pasir Gudang? 


\section{LITERATURE REVIEW}

Teachers' attitudes play a vital role in order to motivate the learners. Gursoy (2013) mentioned that it is essential for practitioners to sustain and promote positive attitudes on English language learning among learners and reflect this positivity in their classrooms. This positive attitude can be seen in the use of various teaching techniques in their classroom. For example, Azizizadeh (2007) investigated Iranian EFL teachers' attitude and teaching techniques in small and large classes. He revealed that there was no any significant difference between the attitudes among novice and expert teachers in using teaching techniques in their different class sizes. This shows that every practitioner is using their preferred teaching techniques to teach their pupils in ESL classrooms. In this section, the teaching techniques that we focused were interactive technology, interactive whiteboard and interactive slides.

\section{A. Interactive Technology}

Interactive technology mainly focuses on the use of ICT in classroom. Teachers usually use interactive technology to facilitate their TnL process (Razavi, Ghanizadeh, \& Akbari, 2016). Kennelwell (2005) revealed that some pupils could remember the input given by teachers when ICT was used in their learning. Besides, the lessons become interesting when the teacher is using computer to teach rather than only talking takes place in the classroom. Learners could also remember things, learn more, present ideas when they are using Powerpoint to do presentation in class. Ghanizadeh and Razavi (2015) supported that students can have a positive progress in different educational context generally when various technologies are being used. For instance, using ICT in classroom helps to facilitate teaching, learning and evaluation. This is aligned with the other researches conducted whereby use of IS and ICT generally enhances effective teaching (Oz, 2014; Ghavifekr \& Wan Athirah, 2015; Valasidou, Sidiropoulos, Hatzis, \& Bousiou-Makridou, 2005). The use of multimedia technology also creates an authentic learning situation and motivate learners. The result of their study also revealed that using modern technologies in classroom improves the quality of input between teachers and students, authenticity of communication and gives more relevant and beneficial feedback. As for language learning, multimedia information system helps in integrating and instructing writing, reading, listening and speaking skills (Razavi et al., 2016). Funkhouser (2003) stated that even very guided tutorial multimedia CDROM combining texts, videos, and audios involves $\mathrm{TnL}$ activities ranging from dialogue work, vocabulary training, and listening skills in one medium. As for reading skill, Smart School Software not only gives a positive and high impact on learners' reading comprehension ability but the retention of reading materials, too (Rostami, Akbari, \& Ghanizadeh, 2015). Therefore, the use of interactive technology gives a positive impact for students who are having problems to perform well in their reading skill. Simultaneously, it reduces the burden and worry of the teachers. Khiyabani (2014) mentioned that using multimedia in teaching helps learn and acquire unknown vocabulary more effective than using traditional methods of teaching. It provides a positive effect on the retention of vocabulary knowledge and also bridges to a deeper comprehension. Students have a positive attitude in learning new vocabulary since they are mostly attached to technology in their daily lives. Hence, when technology is used in classroom learning, they tend to explore more and are interested to learn new vocabulary.

Since teachers have different levels of confidence and competence with technologies (Kennewell, Tanner, \& Parkinson, 2000), they were provided sufficient training in order to improve their ability. For instance, in United Kingdom, teachers have the opportunity to explore the computer software and share knowledge with their colleagues (Ofsted, 2004). This provides more rooms for teachers to explore and have a deep understanding about using interactive technology in their classrooms. Besides, Kennewell (2005) found that the practitioners' interaction with students were planned earlier and it was able to prepare proper multimedia teaching materials as the access to ICT is available in their classrooms. Furthermore, the use of technology in classroom could help in enhancing instruction through scaffolding students' concrete learning (Gimbert \& Cristol, 2004). The use of multimedia (computer) in classrooms becomes a platform for teachers and learners to exchange ideas and communicate through sound and texts. Hence, an effective TnL process takes place through the use of interactive technology.

\section{B. Interactive White Board}

The Interactive Whiteboard (IWB) is a giant sensitive board that is connected to a computer and digital projector, which reflects the computer's image onto a big touchable computer screen controlled electronic pen or finger (Katwibun, 2014). This technology enables students to learn faster and effectively while for teachers, it helps to bring back mandatory creative autonomy (Glover, Miller, Averis, \& Door, 2005). Katwibun (2014) revealed that students show a positive result in academic achievement, participation in classroom and also their attitude because they are more interested to pay attention on the lesson in classroom. The learners are attracted to the use of IWB in teaching. Apart from that, Cuthell (2005) further supported that teachers who embraced the use of IWB in classrooms allows students to develop and manipulate their cognitive ability through their personal knowledge and understanding of language construction.

Furthermore, students show a better attitude in learning when IWB is used to teach them. Tataroglu (2010) exposed that students have more interest and motivation when IWB is used in their classroom. It obviously increases students' motivation in learning since the presentation is more colourful, has movements and other features that could capture learners' interest (Carr, 1999). Moreover, Kennewell and Beauchamp (2007) claimed that IWB improves both teaching and learning in many ways. These include facilitating better display, giving more visual representation, presenting difficult concepts by providing modelling, and increasing the students' attention span and learning 
experience (Macho, 2005; Yang \& Huang, 2008). While for the teachers, IWB helps them positively increasing pedagogical skills in language teaching process, presentation of new linguistic and cultural elements, interaction among teachers and students and supports the teachers' organizational skills (Bidaki \& Mobasheri, 2013; Buza, 2017).

\section{Challenges of using IS in ESL classrooms}

Lack of ICT resources is a challenge for teachers to use them in their classroom (Chapman \& Mahick, 2004; Mandefro, 2013; Yang \& Huang, 2008). Teachers do not have sufficient facilities to conduct IS during teaching and learning. This will demotivate teachers to implement IS. However, Ghavifekr and Wan Athirah (2015) and Tezci (2011) found that ICT facilities provided in school are not enough nor in good conditions. Time limitation is also one of the challenges of using IS in ESL classroom. Yang and Huang (2008) stated that time constraint discourages teachers to implement IS in the ESL classroom.

D. Ways to encourage teachers to use IS and ICT in ESL classrooms

Ghavifekr and Wan Athirah (2015), Samsonova (2018), Oz (2014) and $\mathrm{Xu}$ (2017) stated that technical supports should be given to the teachers frequently to enhance their competencies in IS and ICT. It can aid the teachers to master ICT skills. Therefore, it meets the demands of the country's education system in the 21 st century teaching skills (Ghavifekr \& Ibrahim, 2015) which focuses on the implementation of ICT in teaching and learning processes. Training interested teachers, and collaboration between the Ministry of Education, educational departments, and schools with ICT organisations in providing technical $(\mathrm{Xu}, 2017)$ and facilities supports are recommended to encourage teachers to use IS and ICT in ESL classroom (Apagu \& Wakili, 2015; Mandefro, 2013).

To conclude, it can be said that most of the teachers are using interactive technology and interactive IWB in their classroom. The use of IS is very limited. This is the gap that we found in our reading which captured our interest to do a research about the perspective of using IS in ESL classrooms.

\section{METHODOLOGY}

This study is a mixed descriptive research design which utilised a set of questionnaires and responded among 179 teachers. Nevertheless, semi-structured interviews were conducted as to support the quantitative data (questionnaires) among five teachers.

\section{A. Questionnaire}

A questionnaire with a total of 17 items (refers to Appendix A) was used as the main instrument in this study. Questionnaire was utilized to collect information in a statistical form. The findings of the questionnaires can easily be quantified by the researchers. The questionnaire was created in Google Drive and sent around to the national school English language teachers in Pasir Gudang via WhatsApp and emails. The questionnaire was designed based on Likert Scale so that respondents could select the best choice that best supports their judgments. The respondents were asked to read the statements given and choose their answers based on 5-Likert scale ranged from 1=Totally Disagree, 2=Disagree, 3=Ambivalent, 4=Agree and 5=Totally Agree. Gee (2017) mentioned that Likert scale can be utilized to gauge somebody's frame of mind by estimating the degree to which they agree or disagree contradicting a specific inquiry or statement. The questionnaire used for this quantitative study was adopted and modified from the original questionnaires designed by Anup and Sanjaya (2016), Ghavifekr and Wan Athirah (2015) and Xu (2017) that were considered suitable for this research.

The questionnaires consisted of 4 sections. It started with the demographic background of the respondents consisted of 5 items that included gender, age group, teaching experience, type of school, highest academic qualification. Section A focused into the effectiveness of using interactive slides in ESL classroom that consists of 7 items. Section B came with 3 items that looked into teacher challenges of using interactive slides in ESL classroom while section C consisted of 2 items that looked into the ways to encourage other teachers to use interactive slides in ESL classroom. The questionnaire was responded by 179 respondents. The number of respondents was selected based on Krejcie and Morgan (1970) table. According to Salant and Dillman (1994), the size of the sample determined by two factors which are the population size and the variety of population concerning the characteristic of interest. In this study, the sample size, and as per his table, a sample size of 179 was sufficient for a population size of 353. Besides, the respondents were from different age group, qualification and school type which matches the criteria of Krejcie and Morgan (1970) table.

\section{B. Semi-structured Interview}

The other instrument used is semi-structured interview. Interviews were conducted to support the results obtained from the questionnaire. In this study, the saturated interview (refer to Appendix B) was carried out five times among the English teachers until there was no new data or information discovered. O'Reilly and Walker (2012) mentioned that when determining on a study design, the researcher should target for one that is explicit regarding how data saturation is reached. Seven questions were asked during the interview which the first three questions focus on the teachers' perspective towards the effectiveness of interactive slides. The fourth question emphasises on the facilities that school should provide to use interactive slides in the classroom while the fifth one looks into the challenges of using interactive slides in ESL classroom. Whereas, the last two question highlight on the ways to upgrade interactive slides skill among the teachers. Table I summarises how the data collection methods and data analysis methods of the current research. 
International Conference on Recents Advancements in Engineering and Technology (ICRAET-18) |15th and 16th March 2019|Siddhartha Institute of Technology \& Sciences, Telangana, India.

Table I: The data collection methods and data analysis methods of the current research

\begin{tabular}{|c|c|c|}
\hline Research Questions & $\begin{array}{c}\text { Data Collection } \\
\text { Methods }\end{array}$ & $\begin{array}{c}\text { Data } \\
\text { Analysis } \\
\text { Methods }\end{array}$ \\
\hline $\begin{array}{l}\text { RQ1: What is the } \\
\text { teachers' perspective on } \\
\text { the effectiveness of } \\
\text { using Interactive Slides } \\
\text { (IS) in ESL classroom } \\
\text { among primary school } \\
\text { English Language } \\
\text { teachers in Pasir } \\
\text { Gudang? }\end{array}$ & $\begin{array}{l}\text { 1. Questionnaire } \\
\text { 2. Semi } \\
\text { structured } \\
\text { interview (to } \\
\text { support } \\
\text { questionnaire) }\end{array}$ & $\begin{array}{l}\text { Descriptive } \\
\text { Analysis } \\
\text { (percentage, } \\
\text { mean and } \\
\text { standard } \\
\text { deviation). }\end{array}$ \\
\hline $\begin{array}{l}\text { RQ2: What is the } \\
\text { teachers' perspective on } \\
\text { the challenges of using } \\
\text { IS in ESL classroom } \\
\text { among primary school } \\
\text { English Language } \\
\text { teachers in Pasir } \\
\text { Gudang? }\end{array}$ & $\begin{array}{l}\text { 1. Questionnaire } \\
\text { 2. Semi } \\
\text { structured } \\
\text { interview (to } \\
\text { support } \\
\text { questionnaire) }\end{array}$ & $\begin{array}{l}\text { Descriptive } \\
\text { Analysis } \\
\text { (percentage, } \\
\text { mean and } \\
\text { standard } \\
\text { deviation). }\end{array}$ \\
\hline $\begin{array}{l}\text { RQ3: What is the } \\
\text { teachers' perspective on } \\
\text { the ways to encourage } \\
\text { teachers to use IS in ESL } \\
\text { classroom among } \\
\text { primary school English } \\
\text { Language teachers in } \\
\text { Pasir Gudang? }\end{array}$ & $\begin{array}{l}\text { 1. Questionnaire } \\
\text { 2. Semi } \\
\text { structured } \\
\text { interview (to } \\
\text { support } \\
\text { questionnaire) }\end{array}$ & $\begin{array}{l}\text { Descriptive } \\
\text { Analysis } \\
\text { (mode). }\end{array}$ \\
\hline
\end{tabular}

\section{FINDING AND DISCUSSION}

The data collected for this research were through questionnaire and interview session. 179 responses were collected randomly from English teachers in national primary schools in Pasir Gudang, Johor. The interview was conducted to five teachers. The following findings are discussed based on three research questions.

Research Question 1: What are the teachers' perspectives on the effectiveness of using Interactive Slides (IS) in ESL classroom among primary school English Language teachers in Pasir Gudang?

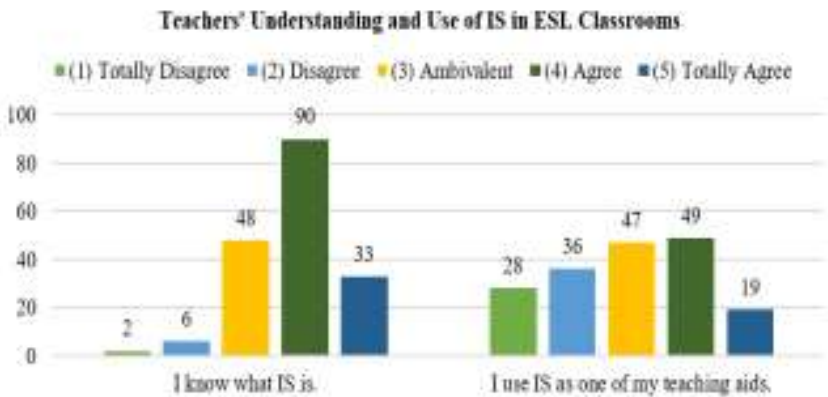

Fig. 1: Teachers' understanding and use of IS in classrooms

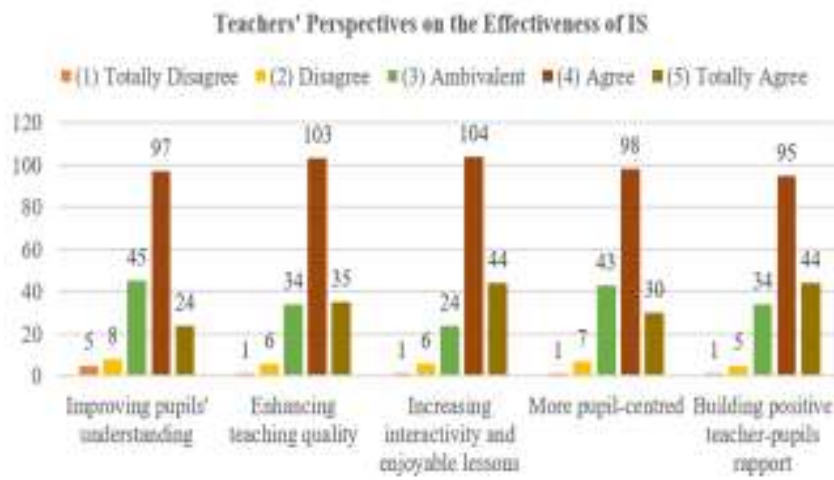

Fig. 2: Teachers' perspectives on the effectiveness of IS in their lessons

Table II: Mean and standard deviations of the items

\begin{tabular}{clll}
\hline No. & \multicolumn{1}{c}{ Items } & Mean & S.D \\
\hline 1. & I know what IS is. & 3.82 & 0.81 \\
\hline 2. & I use IS as one of my teaching aids. & 2.97 & 1.24 \\
\hline 3. & $\begin{array}{l}\text { Students understand better when I use } \\
\text { IS in class. }\end{array}$ & 0.71 \\
\hline 4. & $\begin{array}{l}\text { I believe using IS will improve the } \\
\text { quality of my work and effectiveness } \\
\text { in teaching. }\end{array}$ & 0.75 \\
\hline 5. & $\begin{array}{l}\text { IS makes my lessons more enjoyable } \\
\text { and interactive. }\end{array}$ & \\
\hline 6. & IS is student-centred. & 0.75 \\
\hline 7. & $\begin{array}{l}\text { IS helps teachers and students build } \\
\text { good relationship. }\end{array}$ & 3.98 & 0.77 \\
\hline
\end{tabular}

Source: Table adapted from Ghavifekr \& Wan Athirah (2015)

Fig. 1 shows teachers' understanding and use of Interactive Slides (IS) in their classroom. Based on the data, 33 teachers with $18.4 \%$ agreed that they fully understand the concept of IS. It was followed by 138 teachers $(77.1 \%)$ who are merely familiar with the concept, and 8 of them $(4.5 \%)$ are not aware about it. Furthermore, 19 which was $38 \%$ of the teachers agreed that they are using IS regularly in their language lessons, 129 of them $(72.1 \%)$ use IS occasionally and 64 of them which was $35.7 \%$ do not use it in their classroom. From the overall data in Table 4.1, the teachers are familiar with the concept of IS with the score mean 3.82. This showed that they are likely exposed, however, do not fully understand IS. It also reveals that the teachers seldom use IS in their ESL classroom (mean $=2.97)$. Based on the data, the researchers found that most of the teachers are aware of IS but they are not using it as one of their teaching aids frequently in the classroom. This is supported by an interview session with a teacher that said IS is only used in language arts classes and during classroom observation.

Fig. 2 illustrates the perspectives on the effectiveness of using IS in the ESL lessons among the teachers. It can be observed that majority of the teachers which was 121 of them $(67.6 \%$, mean $=3.71)$ believed and agreed that IS is able to improve pupils' understanding on the learning contents. Moreover, 138 teachers $(77.1 \%$, mean $=3.92)$ stated that IS

further enhances their 
teaching quality and effectiveness. 148 teachers with $82.7 \%$ (highest mean=4.03) claimed that it is interactive and enjoyable among pupils. This shows that IS potentially help teachers to create interactive learning environment. Furthermore, $128(71.5 \%)$ and $139(77.7 \%)$ teachers supported that IS is pupil-centred (mean $=3.83$ ) and able to build positive teacher-pupil rapports (mean = 3.98), respectively. Thus, it promotes positive learning environment and proves that the use of IS in classes leads to effective lessons.

The findings show that teachers believe and agree that using IS in ESL classrooms is effective and useful. Indeed, IS is one of the subordinate elements of ICT. The results are in line with researches conducted $(\mathrm{Oz}, 2014$; Ghavifekr \& Wan Athirah, 2015; Valasidou, Sidiropoulos, Hatzis, \& Bousiou-Makridou, 2005) that proved most teachers agreed that the use of ICT elements will definitely provide lots of opportunities for an effective teaching. Additionally, the use of ICT during lessons can increase the quality of teaching (Bidaki \& Mobasheri, 2013; Buza, 2017) by enhancing pupils' learning experience (Macho, 2005; Yang \& Huang, 2008). In short, teachers acknowledge the effectiveness and positive effects (Kennewell \& Beauchamp, 2007) of using IS in their classes.

Research Question 2: What are the teachers' perspectives on the challenges of using IS in ESL classroom among primary school English Language teachers in Pasir Gudang?

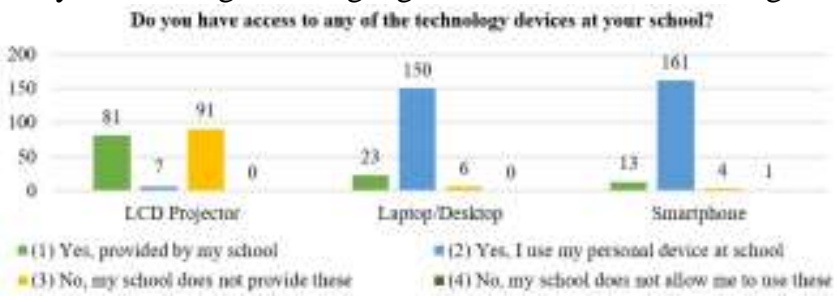

Fig. 3: Teachers' accessibility to technology devices at school

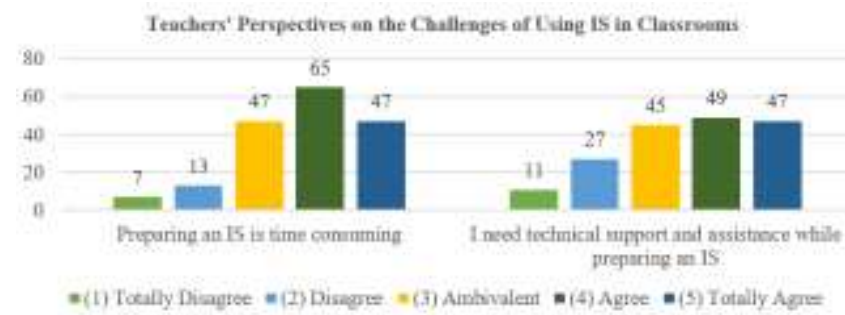

Fig. 4: Teachers' perspectives of challenges in using IS in classrooms

Table III: Mean and standard deviations of the items

\begin{tabular}{|c|c|c|c|}
\hline No. & Items & Mean & S.D \\
\hline 1. & $\begin{array}{l}\text { Do you have access to any of the } \\
\text { technology devices at your school? }\end{array}$ & & \\
\hline & LCD projector & 2.06 & 0.98 \\
\hline & Laptop/ Desktop & 1.91 & 0.39 \\
\hline & Smartphone & 1.96 & 0.34 \\
\hline 2. & Preparing an IS is time-consuming. & 3.74 & 1.05 \\
\hline 3. & $\begin{array}{l}\text { I need technical supports and } \\
\text { assistance while preparing an IS. }\end{array}$ & 3.53 & 1.21 \\
\hline
\end{tabular}

Source: Table adapted from Ghavifekr \& Wan Athirah (2015)
Fig. 3 shows the teachers' accessibility to technology devices at their school. 161 respondents (89.9\%) are using their own smartphones in school while one of them $(0.6 \%)$ mentioned that the school restricts the use of this gadget Besides, 150 respondents $(83.8 \%)$ are using their own laptops/desktops, apparently, only 23 respondents (12.8\%) are provided with these devices in schools. Moreover, 81 respondents $(45.3 \%)$ mentioned that $\mathrm{LCD}$ projector is provided in their schools while a higher percentage $50.8 \%$ of them (91 respondents) claimed that there is no projector provided. Hence, based on the overall data, the teachers are facing shortage of available ICT facility to conduct lessons using IS. This is supported by two interviewees stating that limited number of projectors is available in their schools. Lack of ICT resources is a challenge for teachers to use them in their classroom (Chapman \& Mahick, 2004; Mandefro, 2013; Yang \& Huang, 2008). Subsequently, teachers have to compete for the projectors and that discourages them to prepare IS. As the same time, teachers mostly are using their own laptops/ desktops (mean=1.91) and smartphones (mean=1.96) in their schools. This can challenge them to prepare and implement IS in their ESL classrooms, especially those who do not own these devices.

Fig. 4 reveals the teachers' perspectives of challenges in using IS in classrooms. Most of the teachers $(f=112,62.6 \%$; mean $=3.74$ ) agreed that preparing IS is time consuming. This is supported through the interviews, the teachers said that they need at least two weeks to prepare an IS. This can be justified by Yang and Huang (2008) stating that time constraint discourages teachers to implement it. It is because majority of them ( $\mathrm{f}=96,57.7 \%$; mean=3.53) stated that they require technical supports and assistance while preparing the slides. This is supported by the interviews conducted, three teachers added that they are new to IS and hence, they are lack of exposure to IS. One of them also mentioned that it is very challenging for her to explore and prepare IS as she is not familiar with IS software. The interview also revealed that teachers are lacked of hands-on courses and workshop related to IS preparation and implementation. This view is also further supported by some researchers (Akkoyunlu \& Baskan, 2015; Chapman \& Mahick, 2004; Yang \& Huang, 2008) claiming that lack of teacher training can challenge teachers to use certain technology in their lessons. The findings obtained also were aligned with the studies conducted (Ghavifekr \& Wan Athirah, 2015; Tezci, 2011) in which they found that most teachers agree ICT integration is effective, but ICT facilities provided in school are not enough nor in good conditions.

Research Question 3: What are the teachers' perspectives on the ways to encourage teachers to use IS in ESL classroom among primary school English Language teachers in Pasir Gudang? 
Interactive Slides Skills Upgrading Activities or Programs

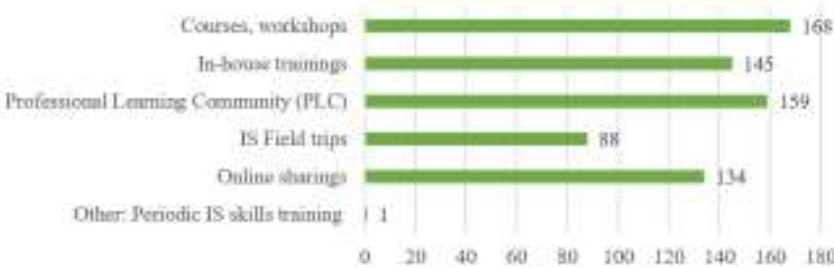

Fig. 5: Activities or programs suggested to upgrade IS skills among ESL teachers

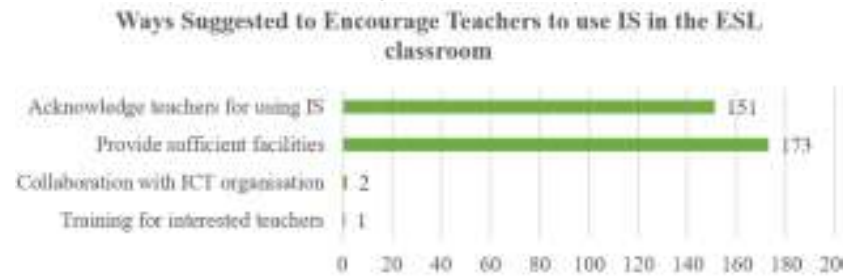

Fig. 6: Ways to encourage teachers to use IS in the ESL classroom

Fig. 5 depicts activities or programs suggested to upgrade IS skills among ESL teachers while Fig. 6 illustrates the ways to encourage teachers to use IS in their classrooms. Courses and workshops were the most recommended programs in order to upgrade teachers' skills in managing IS in which there were 168 respondents with $93.9 \%$ of the samples suggesting it. Followed by Professional Learning Community (PLC) $(\mathrm{f}=159,88.8 \%)$ and in-house training $(\mathrm{f}=145,81 \%)$ are the subsequent suggested activities or programs. Besides, the other two activities or programs chosen by respondents were create IS field trip $(\mathrm{f}=88,49.2 \%)$. There was one respondent further suggested that trainings on IS preparation should be provided from time to time. The suggestions are aligned with the recommendations provided by some scholars (Ghavifekr \& Wan Athirah, 2015; Samsonova, 2018; Oz, 2014; Xu, 2017) stating that technical supports should be given to the teachers frequently to enhance their competencies in IS and ICT which meets the demands of the country's education system in the 21 st century teaching skills (Ghavifekr \& Ibrahim, 2015).

Apart from that, 173 with $96.6 \%$ of respondents suggested that the provision of sufficient facilities for the teachers can encourage the use of IS in ESL classrooms. 151 with $84.4 \%$ respondents proposed that teachers need acknowledgement for using IS in their classroom. In addition, there were further suggestions to train interested teachers, and to have collaboration between the Ministry of Education, educational departments and schools with ICT organisations in providing technical (Xu, 2017) and facilities supports (Apagu \& Wakili, 2015; Mandefro, 2013).

\section{CONCLUSION AND RECOMMENDATION}

"Professors must embrace change and view it as a chance to augment, extend, and in some cases rejuvenate their teaching" (Celsi \& Wolfinbarger, 2002, p. 64). Teachers should adapt to the ongoing changes in technology, and use them extensively in the learning process (Buza, 2017). This research revealed the teachers' perspective on the effectiveness of the use of Interactive Slides is highly encouraging. Interactive slides (IS) also provides a positive paradigm in ESL classrooms to Online Sharing via Blogs and Facebooks ( $\mathrm{f}=134,74.9 \%)$ and

improve teaching and learning processes in primary schools (Macho, 2005). Similar to Interactive Technology (Eastman, 2007), Interactive Slides helps to develop communication among teachers and the pupils through increased interaction and positive rapports (Valasidou, Sidiropoulos, Hatzis, \& Bousiou-Makridou, 2005). This is to meet 21st century learning that require teachers to bring them forward and adapt to the new educational standards and techniques. IS entails student centred learning where teachers play the role of facilitators and resource persons to provide students the opportunities to engage themselves (Samsonova, 2018). However, there are challenges for teachers to use IS in their lesson as revealed in our findings. Those are lack of facilities (Ghavifekr \& Wan Athirah, 2015; Tezci, 2011), exposure to IS preparation and time consuming (Chapman \& Mahick, 2004). Hence, teachers should upgrade their skills in using IS through activities and programs such as courses, workshops and PLC sessions. At the same time, teachers could be encouraged to use IS by providing sufficient facilities in classroom (Ghavifekr \& Wan Athirah, 2015). Here, it can be highlighted that the teachers' effort is vital in order to use IS in their classroom.

Further research is needed with larger scale of respondents in order to measure perspectives of using Interactive Slide (IS) in ESL classroom. It is also recommended to conduct future researches in different settings (other districts and states). By doing so, the researchers can collect more data regarding teachers' perspective of using IS from different areas, hence, this can further validate and generalise the results obtained. Besides, the research can focus on the implementation of IS in ESL classroom by conducting action researches. Thus, it would reveal the effectiveness of using IS in real classroom settings. This case study hopes to contribute to the literature by prompting discussion and further research on this topic.

\section{REFERENCES}

1. Akkoyunlu, B., \& Baskan, G. (2015). School principals' opinions on the Faith project in Turkey. International Conference on New Horizons in Education, (pp. 1497-1502). Paris, France. doi:10.1016/j.sbspro.2015.01.780

2. Anup, K. D., \& Sanjaya, M. (2016). Questionnaire on learner use of technology. In A. Kirkwood, \& L. Price (Eds.), Handbook, Technology-Enabled Learning Implementation (pp. 59-68) Commonwealth of Learning.

3. Apagu, V. V., \& Wakili, B. A. (2015). Availability and utilization of ICT facilities for teaching and learning of vocational and technical education in Yobe State Technical Colleges. American Journal of Engineering Research (AJER), 4(2), 113-118.

4. Azizizadeh, S. (2007). Review of effectiveness of creativity training on improvement of entrepreneurial attitude in unemployed people in Tehran City (Master Thesis). Allameh Tabatabaei, Faculty of Psychology \& Educational Sciences.

5. Bidaki, M. Z., \& Mobasheri, N. (2013). Teachers' views of the effects of the Interactive White Board (IWB) on teaching. Procedia - Social and Behavioural Sciences, 140-144.

6. Buza, K. (2017). The role of the teachers in the integration of ICT in teaching in secondary low education. European Journal of Social Sciences, Education and Research, 4(4), 240-247.

7. Carr, L. (1999). Bringing lessons to life. Managing Schools Today, 9(1), 14. 
8. Celsi, R. L., \& Wolfinbarger, M. (2002). Discontinuous classroom innovation: Waves of change for marketing education. Journal of Marketing Education, 24(1), 64.

9. Chapman, D., \& Mahick, L. (2004). Adapting technology for school improvement: A global perspective. Paris: International Institute for Educational Planning.

10. Cuthell, J. P. (2005). Seeing the meaning: The impact of interactive whiteboards on teaching and learning. Proceedings of WCCE 05. Stellenbosch. South Africa.

11. Eastman, J. K. (2007). Enhancing classroom communication with Interactive Technology: How faculty can get started. College Teaching Methods \& Styles Journal, 3(1), 31-38.

12. Funkhouser, C. (2003). The effects of computer-augmented geometry instruction on student performance and attitudes. Journal of Research on Technology in Education, 35, 163-175. doi:http://dx.doi.org/10.1080/15391523.2002.10782377

13. Gee. (2017, July 19). Advantages of Using Likert Scale Questions. Retrieved April 1, 2019, from Smart Survey: https://blog.smartsurvey.co.uk/advantages-of-using-likert-scalequestions

14. Ghanizadeh, A., \& Razavi, A. (2015). The impact of using multimedia in English high school classes on students' language achievement and goal orientation. International Journal of Research Studies in Educational Technology, 4(2), 31-42. doi:http://dx.doi.org/10.5861/ijrset.2015.1183

15. Ghavifekr, S., \& Ibrahim, M. (2015). Effectiveness of ICT integration in Malaysian schools: A quantitative analysis. International Research Journal for Quality in Education, 2(8), $1-12$

16. Ghavifekr, S., \& Wan Athirah, W. (2015). Teaching and learning with technology: Effectiveness of ICT integration in schools. International of Journal of Research in Education and Sciences (IJRES), 1(2), 175-191.

17. Gimbert, B., \& Cristol, D. (2004). Teaching Curriculum with technology: Enhancing children's technology competence during early childhood. Early childhood Education Journal, 31(3), 207-216.

18. Glover, D., Miller, D., Averis, D., \& Door, V. (2005). The interactive whiteboard: a literature survey. Technology, Pedagogy and Education, 14(2), 155-170.

19. Gursoy, E. (2013). Prospective ELT teachers' attitude toward the English Language in an EFL context. Journal of International Education Research, 9(1), 107-114

20. Katwibun, H. (2014). Using an interactive whiteboard in vocabulary teaching. 5th World Conference on Educational Sciences - WCES 2013 (pp. 674 - 678). Elsevier Ltd. doi:10.1016/j.sbspro.2014.01.278

21. Kennewell, S. (2005). Interactive Teaching with Interactive Technology. Hendrefoelan: Swansea.

22. Kennewell, S., \& Beauchamp, G. (2007). Features of interactive whiteboards. Learning, Media and Technology, 32(3), 227-241.

23. Kennewell, S., Tanner, H., \& Parkinson, J. (2000). Developing the ICT capable school. London: RoutledgeFalmer.

24. Khiyabani, H. (2014). Using multimedia in teaching vocabulary in high school classes. Journal of Advances in English Language Teaching, 2(1), 1-13.

25. Krejcie, R. V., \& Morgan, D. W. (1970). Determining sample size for research activities. Educational and Psychological Measurement, 30, 607-610.

26. Macho, S. (2005). Differences among standardized test scores due to factors of internet access at home and family affluence. United States: West Virginia University.

27. Mandefro, E. (2013). An assessment of the availability and utilazation of ICT facility for teaching and learning purpose in selected secondary schools of Sidama Zone (Master Thesis). Ethiopia: Hawassa University.

28. Ministry of Education. (2015). Executive Summary Malaysia Education Blueprint 2013-2025 (Preschool to Post-Secondary Education). Retrieved April 1, 2019, from http://www.moe.gov.my/cms/upload_files/articlefile/2013/articl efile_file_003114.pdf.

29. O'Reilly, \& Walker. (2012). Data saturation in quality research Retrieved April 1, 2019, from https://cpb-us-e1.wpmucdn.com/sites.nova.edu/dist/a/4/files/20 15/09/fusch1.pdf

30. Ofsted. (2004). ICT in schools: The impact of government initiatives five years on. London: Ofsted. Retrieved from http://www.ofsted.gov.uk/publications/index.cfm?fuseaction=p ubs.displayfile $\& \mathrm{id}=3652 \&$ type $=$ pdf

31. Oz, H. (2014). Teachers' and students' perceptions of interactive whiteboards in the English as a Foreign Language Classroom. TOJET: The Turkish Online Journal of Educational Technology, 13(3), 156-177

32. Razavi, A., Ghanizadeh, A., \& Akbari, O. (2016). Teachers' perceptions of the use of multimedia in teaching English in official and non-official language learning settings. International Journal of Research Studies in Educational Technology, 97-109.

33. Rostami, S., Akbari, O., \& Ghanizadeh, A. (2015). The effect of smart school programs on EFL reading comprehension in an academic context. International Journal of Research Studies in Educational Technology, 4(1), 1-10. doi:http://dx.doi.org/10.5861/ijrset.2014.936

34. Salant, \& Dillman . (1994). Sample size estimation using Krejcie and Morgan And Cohen statistical power analysis: A comparison. Retrieved April 1, 2019, from https://www.academia.edu/8303970/SAMPLE_SIZE_ESTIMA TION_USING_KREJCIE_AND_MORGAN_AND_COHEN_S TATISTICAL_POWER_ANALYSIS_A_COMPARISON

35. Samsonova, O. (2018). Elementary teachers' uses and perceptions of Interactive whiteboards for instruction. International Journal of Learning, Teaching and Educational Research, 17(8), 17-35.

36. Tataroglu, B. (2010). Examining students' attitudes and views towards usage an interactive whiteboard in mathematics lessons. Procedia Social and Behavioral Sciences, 2533-2538.

37. Tezci, E. (2011). Factors that influence preservice teachers' ICT usage in education. European Journal of Teacher Education, 34, 483-499.

38. Valasidou, A., Sidiropoulos, D., Hatzis, T., \& Bousiou-Makridou, D. (2005). Guidelines for the Design and Implementation of E-Learning Programmes, Proceedings of the IADIS. International Conference IADIS E-Society 2005. Qawra, Malta.

39. Xu, X. H. (2017). Study on effective using of multimedia teaching system and enhancing teaching effect. Internation Journals of English Teaching (iJET), 12(6), 187-195.

40. Yang, S., \& Huang, Y. (2008). A study of high school English teachers' behaviour, concerns and beliefs in integrating information technology into English instruction. Computers and Human Behavior, 24(3), 1085-1103. doi:http://dx.doi.org/10.1016/j.chb.2007.03.009

\section{AUTHORS PROFILE}

Tan Hon Kian, Faculty of Social Sciences and Humanities, Universiti Teknologi Malaysia, Skudai, Johor, Malaysia.

Tharani A/P Paramasivam, Faculty of Social Sciences and Humanities Universiti Teknologi Malaysia, Skudai, Johor, Malaysia

Kokilavathi A/P Paramesvaranm, Faculty of Social Sciences and Humanities, Universiti Teknologi Malaysia, Skudai, Johor, Malaysia.

Selvakumari A/P Sandrasakeren, Faculty of Social Sciences and Humanities, Universiti Teknologi Malaysia, Skudai, Johor, Malaysia. 


\section{Questionnaire:}

Perspectives of Using Interactive Slides in ESL Classrooms (PUIS)

The primary aim of this questionnaire is to know the perspectives of using interactive slides in ESL classrooms among primary school English teachers.

The questionnaire shall be completed by a randomly selected stratified sample of English teachers. The study uses appropriate sample size determination (Krejcie and Morgan) for the survey.

Protecting the privacy of the respondent is important - all personal information will be kept confidential and used only in aggregate form.

Please respond to all the questions by following the instructions.

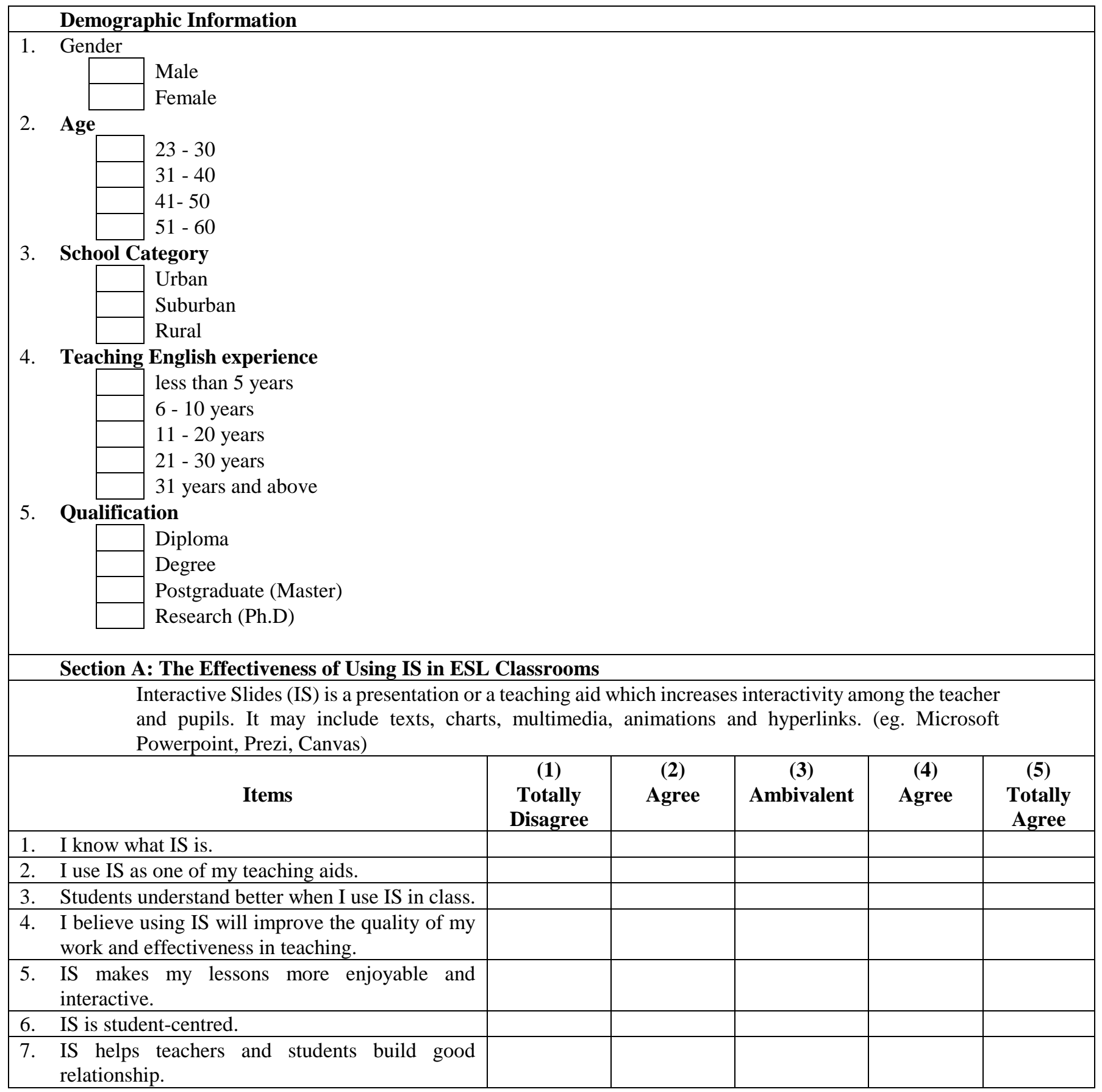




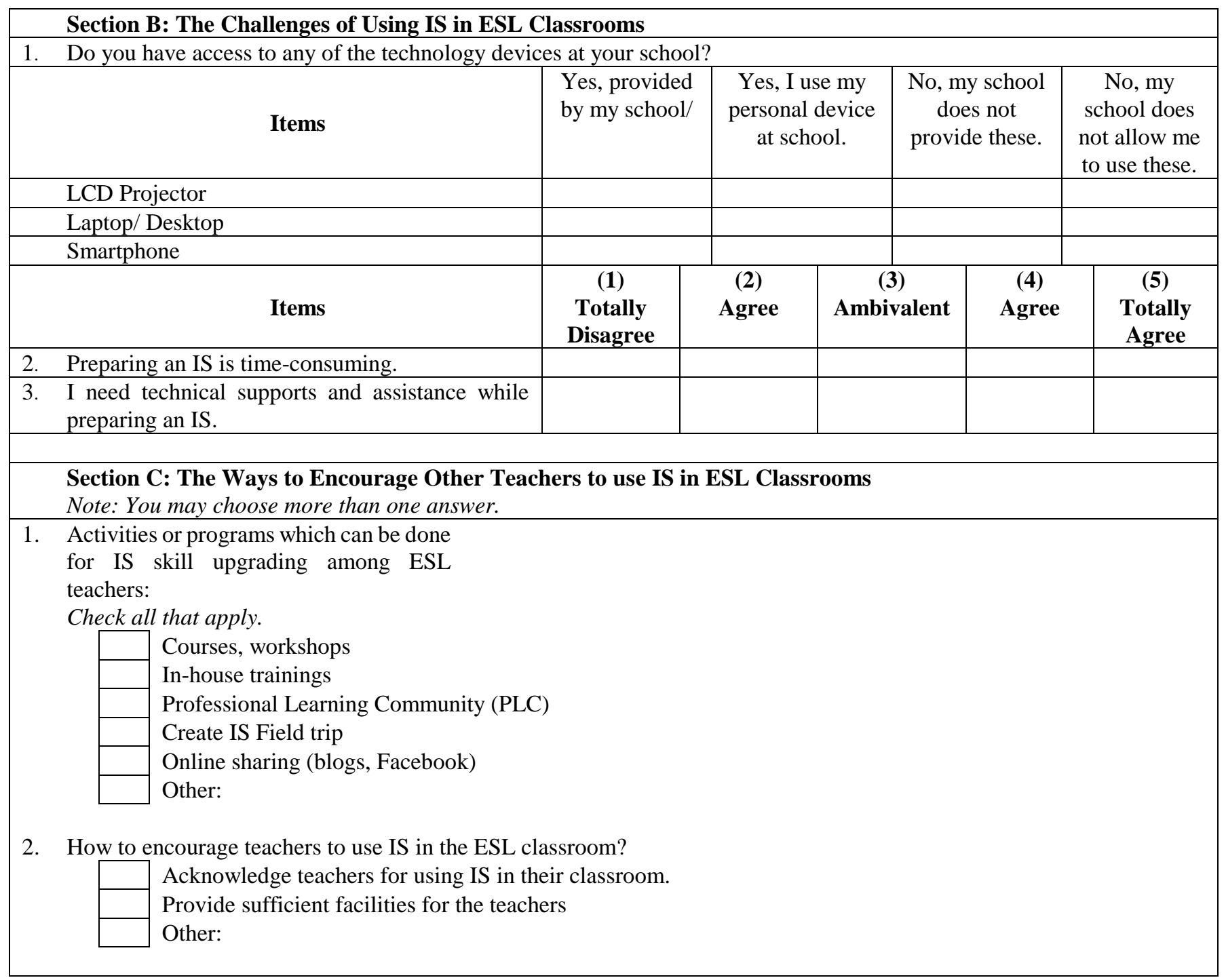


International Conference on Recents Advancements in Engineering and Technology (ICRAET-18) |15th and 16th March 2019|Siddhartha Institute of Technology \& Sciences, Telangana, India.

\section{Semi-structured Interview Questions:}

APPENDIX B

1. Do you think IS is one of the useful teaching aids for teachers? Why?

2. Do you think IS is easier to use in the classroom? Why?

3. Do you think IS makes your work easier? Why do you think so?

4. What are the facilities that schools should provide to use IS in the classroom?

5. What are the challenges of using IS in ESL classroom?

6. What are the activities or programs that can be done to upgrade IS skill among ESL teachers?

7. In your opinion, what are the ways to encourage teachers to use IS in ESL classroom? 